\title{
Labour Resilience and Vulnerable Groups in Times of Crisis: A Comparative Study in Eleven European Countries
}

\author{
Sandra Martínez-Molina \\ Polibienestar Research Institute (University of Valencia), \\ Elisa Valía Cotanda \\ Polibienestar Research Institute (University of Valencia), \\ Jorge Garcés Ferrer \\ Polibienestar Research Institute (University of Valencia),
}

Prince of Asturias Distinguished Visiting Professor at Georgetown University,

\begin{abstract}
The financial crisis which hit the world economies in 2008 has had a negative effect across the spectrum of European economies. These impacts have been felt through the fall in economic activity and also by the deterioration of the labour market indicators. However, not all European markets have been hit with the same severity and intensity, causing territorial differences. But, beyond this, the crisis has had a clear impact on the labour force by exacerbating work inequality. Consequently, the concept of labour emerges through the adaptation of labour markets and the different results obtained amongst the collectives who make up the labour force. The present research has the dual goal of both describing and comparing the labour shock caused by the economic crisis in eleven European countries, establishing differences in employment outcomes of youth (15$24 y$ rs of age), older (55-64yrs of age) and migrants workers by comparing key labour market indicators obtained from official statistical sources. Moreover, it reveals a documented analysis of various national reports describing the employment position of these groups. The results show similarities in the labour vulnerability patterns among countries in each of the groups studied. The analysis highlights the existence of certain factors linked to labour resilience of each group including economic, social, occupational, demographic and political factors. The results of this research are under the INSPIRES project, which has been funded by the Seventh Framework Programme of the European Commission.
\end{abstract}

Keywords: Labour market, financial crisis, unemployment, resilience, vulnerable groups

\section{Introduction}

The world financial crisis of 2008 has had an effect across the spectrum of European economies. The impacts of this crisis have been felt through the fall in GDP of European economics and also by the deterioration of the main labour market indicators (Brada and Signorelli, 2012; Eichhorst, Escudero, Marx \& Tobin, 2010; Lallement, 2011; Marelli, Signorelli \& Tyrowicz, 2012; Vaughan- Whitehead, 2011). However, not all the European countries have been hit with the same severity and intensity. Some labour markets have been more responsive to the economic downturn, causing diverse territorial differences on labour since 2008. Beyond this, the crisis has also shown a divergent effect on the different groups of the labour force, exacerbating work inequality.

Accordingly, the concept of labour resilience emerges as an important pillar explaining the adaptation of labour markets and the differences in results obtained by the labour force collective. Hence, this document has the dual goal of both describing and comparing the labour shock caused by the economy on youths, older and migrant workers in eleven 
European countries, namely: Belgium, Germany, Greece, Hungary, Italy, Slovenia, Spain, Sweden, Switzerland, the Netherlands and the U.K.

To this end, the present paper is structured as follow: the "Theoretical framework" part addresses the differential impact of the crisis on European countries and workforce, paying special attention to those factors affecting the resilience of young, old and migrant workers. In the "Method" section we provide a description of indicators, operational definitions and sources used in this study. The "Result" section shows the main findings of the analysis; finally, in the section "Discussion and conclusion" the main conclusions of this study are presented.

\section{Theoretical Framework}

\section{The crisis impact on labour markets and vulnerable groups}

The impact of the economic crisis in Europe has shown a remarkable, although differential, effect on labour markets (Brada \& Signorelli, 2012; Eichhorst et al., 2010; Lallement, 2011; Marelli et al., 2012; Vaughan- Whitehead, 2011). Although the crisis impact has hardly left its mark on the labour market in some countries, the deterioration process has been intense and long lasting in others, causing several territorial differences. From the differential impact on labour figures, the concept of resilience applied to the labour market is an important factor explaining the adaptation of markets as well as differences in labour force results (Bigos, Qaran, Fenger, Koster, Mascini \& Van deer Veen, 2013; Fenger, Koster, Struyven \&Van deer Veen, 2014; Murias, Martínez-Roget, Novello \& Estévez-Núñez, 2012; OECD 2012).

Generally speaking, resilience is used to describe a positive feature or ability of a system to bounce back to a previous favourable state after a shock (Bahadur, Ibrahim \& Tanner, 2010; Cuadrado-Roura, Martin \& Maroto 2016; Lisnyak, 2015; Martin, 2012; Martin \& Sunley 2014; Simmie \& Martin 2010). In the recent years of crisis, this concept has also been applied to the labour markets in order to understand the differences in labour dynamics by country and region (Fenger et al., 2014; OECD, 2012; Chapple \& Lester, 2010) and by vulnerable group (Bigos et al., 2013). Indeed, Bigos et al. (2013) define labour market resilience not only as the capacity of labour markets to absorb external shocks but also to mitigate their impact for employment levels, specifically for vulnerable groups (Bigos et al., 2013:1).

As argued by (Andrei \& Saša, 2011) some groups in the labour market can be called vulnerable since they have a less favourable performance in the labour market key indicators compared to the working age population. Thus, whilst it is true that some groups may experience greater job vulnerability even in times of economic growth, the crisis has shown ea diverse impact on the different groups, exacerbating work inequalities (Caporale \& Gil-Alana, 2014; Choudhry, Marelli, E. \& Signorelli, 2010; European Commission, 2011; European Commission, 2012a; Vaughan- Whitehead, 2011). In line with more recent literature (Bigos et al., 2013) this study focuses on three groups, young people, migrants and older worker, which are regarded as vulnerable (see Table 1).

(Here table 1)

\section{Factors affecting labour resilience of vulnerable groups}

According to OECD (2012) there is a relationship between good labour results and resilience. As consequence, those factors impacting in a negative way on the labour results of groups making up labour force might reduce their labour market resilience by increasing their labour market vulnerability. Specifically, this section goes in depth on factors affecting labour resilience of youths, older and migrant workers.

In line with literature, it has been argued that age affects negatively unemployment rates, in other words there is a direct relationship between age and unemployment rates (European Commission, 2012a). As a matter of fact, in European countries young people have been especially affected by unemployment levels during the crisis. Their unemployment level has been nearly twice as high as other age groups as a general trend (Vaughan-Whitehead, 2011). In view of this, some factors such as economic, educational and institutional issues have been stressed as important and it has been argued that youth labour behaviour is strongly influenced by the economic business cycle (Choudhry et al., 2010; Caporale \& GilAlana, 2014). Consequently, some studies highlight the importance of macroeconomic variables such as GDP and the sectorial composition of employment before the crisis in youth unemployment (Caporale \& Gil-Alana, 2014; Verick, 2009). According to Kuddo (2012) youths might be more affected by negative shocks due to the fact that their productivity is 
generally lower given differences in skills and experience. However, besides the high rates of unemployment, young people are also suffering strong difficulties in obtaining a good job. According to ILO (2010), young people are more likely to find themselves working with insecure arrangements characterized by low productivity, low wages and limited labour protection.

Age, therefore, has been a condition affecting the results of some labour markets. Consequently, older workers, as a collective, usually enjoy better labour conditions compared to other vulnerable groups. However, factors such as skills, discrimination and health issues might be crucial in their labour outcomes. Thereby, the European Commission (2012b) has indicated the importance of training for older workers since their participation rates in the labour market are highly correlated with levels of skill. Older workers who have higher qualifications also have higher rates of participation in the labour market. Similarly, Eurofound (2011) indicates that older people with higher educational attainment tend to stay in employment longer. However, some negative perceptions of employees aged 55 years and over have been noted. Whilst they are perceived as experienced and reliable, they are less likely to be considered open to new ideas or up to date with new technologies, resulting in a potential limitation of their employability (Eurobarometer, 2012). Moreover, health issues might also affect this group. According to the European Agency for Safety and Health at Work (2009) some changes such as the gradual decline in some abilities or physical capacity and the decline of some psychophysical capabilities, can affect their possibilities to find work and their employment permanence. In addition, older workers are also more likely to be working part-time than other workers as well as choose early retirement options (Eurofound, 2011).

Nationality has also had an impact on labour market results (European Commission, 2012a). According to the European Commission (2012b) the employment rate of migrant people is more sensitive to economic cycles. Moreover, migrants have been affected by unemployment and by low quality jobs. This fact has been related to the arrival of low-skilled migrants and the difficulties they experience in getting their certificates validated, also being effectively used as human capital by the host countries (European Commission, 2012a). Furthermore, according to Bonoli (2012), unskilled migration due to the influx of migrants through different channels, often does not comply with formal contracting, such as asylum claims, familiar reunification or undeclared work. Moreover, migrant people have been considered as a group suffering high discrimination at work (ILO, 2011).

The presented data reflects the continuous challenges that youth, older and migrant workers face in effort join the labour market compared to general population. The main objective of this research is to describe and compare the impact of the crisis on these collectives by comparing key labour market indicators obtained from official statistical sources and desk research in Belgium, Germany, Greece, Hungary, Italy, Slovenia, Spain, Sweden, Switzerland, the Netherlands and the U.K.

\section{Methods}

\section{Methodology, operational definitions and indicators}

In order to obtain a broader and deeper perspective of this study, an analysis of statistical sources together with desk research has been carried out so as to analyse and compare crisis impact on youth, migrant people and older workers in a sample of eleven European countries (See Table 2).

(Here table 2)

In order to study the impact of the crisis on them, several indicators have been selected. Labour vulnerability is often expressed only in quantitative terms with a particular emphasis on unemployment. However, labour vulnerability not only refers to the lack of employment but also jobs characterized by low levels of protection (Rueda, 2012). In order to study the impact of the crisis on these groups, the concept of labour position has been defined as a multidimensional concept which includes quantitative and qualitative aspects of employment. Thus, the quantitative aspects of the labour position refer to the labour participation while the qualitative aspects concern labour conditions. These domains have been operationalized in the following indicators showed in Table 3:

(Here table 3) 
In describing and comparing the impact of the crisis on these groups, statistical data from Labour market statistics ${ }^{1}$ from Eurostat has been used (Table 3). The labour position of each vulnerable group has been compared to the labour position of general population so as to make comparisons of the same group among countries. Specifically, in the study of labour position of youth, migrant people and older workers, the following indicators from Labour market statistics from Eurostat have been selected (Table 4).

(Here table 4)

The indicators showed in Table 4 have been studied from 2000 to 2012 in order to determine the impact of the crisis on the labour position of vulnerable groups.

\section{Results}

In this section the main results of the study are presented in a descriptive and comparative approach between the eleven countries. Using the analysis of the statistical data provided hereafter, the labour market position of three vulnerable groups - young workers, older workers and migrants - between 2000 and 2013 has been assessed on the basis of quantitative and qualitative indicators.

\section{Young workers.}

Figure 1 shows the unemployment rates for young people in the EU28 and all the studied countries. The EU28 average youth unemployment rate was $15.5 \%$ in 2007 . The Netherlands was the country with the lowest youth unemployment rate which was $5.9 \%$ for the same year, followed by Switzerland, Slovenia, Germany and the UK. Conversely, Spain, Hungary, Belgium, Sweden, Italy, and Greece had youth employment rates over the EU28 average.

\section{(Here Figure 1)}

Although the general trend in EU28 was downward for this period- the EU28 average fell 2.8\%- the figures for youth unemployment increased. Belgium, Germany, Hungary, the Netherlands, Sweden, Switzerland and the United Kingdom had higher levels of unemployment in 2007 despite it being a period of economic expansion. Conversely, in Greece, Italy, Slovenia and Spain the tendency was a decrease in the percentage of young unemployed (see table 5).

\section{(Here table 5)}

The indicators established to assess the qualitative dimension of employment are part-time and temporary employment rates. Table 6 shows part-time employment variation between 2000 and 2007. In 2007 in the EU28 25.5\% of people employed between 15 and 24 had a part-time contract. Hungary was the country with the lowest rate with $5.3 \%$, followed by Greece, Italy, Germany, Belgium, Spain and Switzerland. The figures for Hungary and Greece are extremely low in comparison with the rest of the countries - to a minor extent also Italy - and considering that youth unemployment rates for 2007 were over the EU28 average, it is necessary to take into account the data on temporary employment rates ${ }^{2}$ for these countries.

Table 6 shows the evolution of youth part-time employment between 2000 and 2007. According to the literature ${ }^{3}$, part-time employment should not always be considered as a sign of weak job quality. However, the trend followed during the precrisis period, characterized by economic growth, aims at assessing whether the evolution of part-time employment figures 
for people aged between 15 and 24 during the post-crisis period is due to the impact of the crisis or simply follows the same pattern as before 2008. Part-time employment increased among young people on average in the EU28 - $4.5 \%$ between 2000 and 2007. These figures decreased only in Belgium.

(Here table 6)

Figure 2 compares the evolution of youth unemployment rates among the studied countries between 2008 and 2012 . In 2012, the average of the EU-28 was $22.9 \%$ of unemployed young people. Germany and Switzerland were the countries with lowest levels of youth unemployment in 2012, far from the EU28 average, closely followed by the Netherlands. Other countries like Belgium, Slovenia and United Kingdom remained slightly under the EU28 average. Greece and Spain were the two countries where youth unemployment surpassed $50 \%$ in 2012, which represented a real concern. Sweden, Hungary and Italy had an unemployment rate over the European average but did not achieve such bad figures as Greece and Spain.

From a European comparative, there are countries where the labour market position of youth changed in terms of unemployment. Belgium, for example, was over the average in 2008 but 4 years later the unemployment rate for youth was already under the EU28 average.

\section{(Here figure 2)}

Changing the point of view from the evolution of unemployment rates to a comparative perspective of pre-crisis and postcrisis years, some relevant aspects can be highlighted. Countries where the youth unemployment rate followed a downward trend between 2003 and 2007 were Slovenia, Greece, Spain and Italy. These were also the four countries were unemployment increased the most.

(Here table 7)

Table 8 shows temporary employment rates for young people in the studied countries. The percentage of fixed-term contracts among young people followed an upward trend in all countries between 2000 and 2007, with the exception of Greece $(-3.1 \%)$ and Hungary (-6.2\%). The higher rates of temporary employment for those aged between 15 and 24 in 2007 were recorded in Spain, Hungary and Greece, even if the latter two were the sole countries where this rate decreased over this period. The countries where it increased were Spain, Italy and Sweden - from $43.2 \%, 26.2 \%$ and $45.2 \%$ in 2000 to $68.3 \%, 42.3 \%$ and $57.1 \%$ in 2007 , respectively. The most worrying feature is the great difference towards temporary employment rate on average.

(Here table 8)

Figures for Belgium, Switzerland, Germany and Sweden - especially the last two - are remarkable as they changed the tendency followed between 2003 and 2007 and their figures improved between 2008 and 2012. In the post-crisis period unemployment rose slower or even decreased in Germany.

Analysing the data provided in Figure 3, it cannot be stated that in general terms part-time employment increased necessarily as a consequence of the economic crisis. Except for Switzerland, in all studied countries, part-time employment rates for youth rose between 2008 and 2012 (Figure 3). However in many of them - Germany, the Netherlands, Italy and Slovenia - this increase was less intense than between 2003 and 2007. This means that part-time employment started increasing before the economic and financial crisis and that, in some cases, it decreased when the crisis started and in the following years. Special attention should be paid to the Netherlands, whose part-time employment rate after the crisis increased slower than it had done before and where over 76\% of young people were in part-time contracts in 2012. Obviously this high level of part-time employment among young people cannot be a result of the impact of the crisis; this rate has been steadily increasing since before the 2000 s.

(Here figure 3)

\section{Migrant Workers.}


The migrants' unemployment rates were the highest compared to the studied vulnerable groups and the general population average in Germany, the Netherlands and Switzerland. In Greece, migrants' unemployment rates were very similar to the national average or even lower in some years. Unemployment rates for migrants in the EU28 and all the studied countries are represented in Figure 4. In 2007, 12\% of migrant people in the UE28 were unemployed on average. The Netherlands was the only country with the lowest migrant unemployment rate which was $6.5 \%$ in 2007 , followed by Switzerland with $7.1 \%$, Greece, the UK, Italy and Slovenia. In Spain, Sweden, Belgium and Germany migrants had unemployment rates over the EU28 average.

(Here figure 4)

To determine the position of migrants in the labour markets, it is necessary to take into account the evolution of their figures. This is also required in order to ascertain if they were especially hit by the crisis or resisted the impact. As shown in Table 9 the general trend in EU28 was decreasing (1.6\% between 2000 and 2007). The highest gap within the pre-crisis period corresponded to migrant people in Slovenia whose unemployment rate increased $9.7 \%$ over that period. In Italy, Germany and Switzerland, the percentage of unemployed migrants increased from 2000 to 2007. The Dutch, Belgian and Greek migrants' labour market experienced a decrease in unemployment figures under the EU28 average while the Spanish, Swedish and British unemployment rates for migrants decreased more intensively than the EU28 average.

(Here table 9)

Looking at the qualitative indicators, migrants had temporary employment levels over the national average in all studied countries, which indicates that their labour performance could be more precarious even taking into account that they were only more part-time employed than the general average in Germany, Greece, Spain and Italy. It is worth to remark that figures for part-time employment among migrants were favourable in the national context in Belgium, the Netherlands, the United Kingdom and Switzerland, stressing that in the Netherlands and Switzerland the figures for unemployment were more favourable among migrants than the general average.

Temporary employment was also a concern regarding migrants in the studied countries, especially in those where migrants were also affected by long-term unemployment. However, a prevalence of fixed-term contracts always implies weaker job quality and people with this kind of contractual arrangements become more vulnerable towards economic downturn; the risk of not finding a job for a long period increases. Fixed-term contracts were more common among migrants than among the general population in all studied countries (Table 10).

(Here table 10)

One of the indicators that present worse figures over the pre and post-crisis period among the migrant working population compared to the general working population and other groups is the unemployment rate. This rate has been higher than the national average in all studied countries during the post-crisis period, except Greece until 2009, Hungary in 2010 and 2011, and Switzerland in 2008 and 2009.

Figure 5 shows the evolution of unemployment rates of migrant population in the studied countries and the EU28 average. In 2008, $12.2 \%$ of migrants were unemployed in the EU28 on average. The countries with higher rates of migrant unemployment in 2008 were Spain, Sweden, Belgium and Germany and those with the lowest were the Netherlands, Slovenia, Switzerland and Greece.

Taking the post-crisis period evolution into account, Greece, Belgium and Germany need to be mentioned. Greece moved from a very favourable position from a European perspective (being the third country with lower percentage of migrant unemployed) to a quite unfavourable (the second country with the worst figures). So, the unemployment rate among migrant in Greece dramatically increased between 2008 and 2012. Conversely, in Belgium and Germany, migrant working population improved its unemployment rates moving from rates over the EU28 average in 2008 to rates under the EU28 average in 2012.

In 2012, the EU28 average of migrants unemployed was $17.6 \%$. Spain remained the country with the highest rate of unemployment among non-nationals (36.0\%), followed by Greece (33.4\%) and Sweden (21.0\%). 
(Here table 11)

As shown in Table 11, Spain and Greece recorded the widest variation between 2008 and 2012 in percentage points 18.5 and 26.6 respectively. Moreover, unemployment rate in these countries followed a downward trend, so it can be concluded that the crisis definitively impacted on unemployment rates among migrants. The sole country where unemployment rates decreased during the post-crisis period was Germany, with a decrease of $3.7 \%$ changing the upward trend recorded in the previous years.

(Here figure 5)

Migrant are usually also affected by non-voluntary part-time employment. As shown in Table 12 great differences can be observed between the evolution of pat-time employment during the pre-crisis period (2000-2007) and the post-crisis period (2008-2012). Part-time employment increased by 4.5\% on average in the EU28 from 2008 to 2012. Nevertheless, in some countries the evolution of this indicator differed from the EU28 average. In Greece, Spain, the United Kingdom and Slovenia the percentage of migrant people working part-time increased more intensively than in the previous period, especially in Greece and the United Kingdom where this indicator changed the tendency. Especially remarkable is the evolution in Germany and Italy where the increase during the post-crisis period was much slower than it was the years before.

(Here table 12)

(Here figure 6)

\section{Older Workers.}

Older workers had a relatively better position in the labour markets of the studied countries. Only in Germany, older workers had higher unemployment rates between 2000 and 2007 than the general population average. Germany was the country with the highest unemployment rate among older workers during the pre-crisis period, although this rate had a downward trend, decreasing faster than the EU28 average - 2.4\% compared to 1.8\% as EU28 average. Spain had the second highest unemployment rate among older workers between 2000 and 2007. However, in 2007 there was a gap between the German and the Spanish unemployment rate of $4.3 \%-6.0 \%$ in Spain compared to $10.3 \%$ in Germany. The other studied countries had better figures than the EU28 average as shown in Figure 7.

(Here figure 7)

Evolution of unemployment within this vulnerable group decreased of $1.8 \%$ on average in the EU28 (Table 13). Only in Belgium, Hungary, the Netherlands and Switzerland figures increased; the highest increase was in the Netherlands with $1.7 \%, 1.2 \%$ more than the increase of the general population average.

(Here table 13)

The feature that mainly affected older workers during the pre-crisis period was long-term unemployment. Figure 8 shows the figures for long-term unemployment among older workers between 2000 and 2007. As mentioned in this section, older workers had worse long-term unemployment figures in all studied countries in all pre-crisis years than the national average, migrants and youth.

(Here figure 8)

In $2007,63.5 \%$ of older workers were long-term unemployed in the EU28. Belgium had the highest rate $-81.4 \%$ - followed by Germany $(77.1 \%)$ and the Netherlands $(75 \%)$. The rest of the countries had long-term unemployment rates under the EU28 average.

The general trend among the EU28 countries during the pre-crisis period was a slight increase in figures for long-term unemployment of older workers. As Table 14 shows, this rate increased $1.8 \%$ on average in the EU28. However, not all countries followed this trend and we can observe a very different evolution, and very different intensity between the highest increase and the highest decrease. In Slovenia this rate decreased most - from $84.3 \%$ in 2000 to $57.4 \%$ in 2007, i.e. 26.9\%. The country with the highest increase was Switzerland with a gap of $15.9 \%$ between 2000 and 2007 . 
(Here table 14)

In 2012, the EU28 average of unemployed older workers was 7.4\%. In Switzerland (3.1\%), Belgium (4.5\%), the Netherlands $(4.7 \%)$, the United Kingdom (4.9\%), Sweden (5.2\%), Italy (5.3\%), Germany (5.9\%) and Slovenia (6.2\%) unemployment rates for older workers were more favourable than the EU28 average. Conversely, in Hungary (7.9\%), Greece (13.5\%) and Spain (18\%) the percentage of unemployed older workers was higher than the EU28 average. Spain and Greece have the worst unemployment figures for the vulnerable groups - young people, migrants and older workers.

From a European perspective (Figure 9), it is worth mentioning that the sole country where unemployment rates decreased between 2008 and 2012 is Germany - from 8.5\% to 5.9\%. Furthermore, unemployment rates of older workers in Germany were over the EU28 average before the start of the crisis and under the EU28 average in 2012. This has only happened in Germany. On the other hand, Hungary and Greece moved from the group of countries with unemployment rate among older workers under the EU28 average between 2003 and 2007 to the group of country with levels of unemployment among older workers over the EU28 average between 2008 and 2012. The country with better unemployment figures both in the pre and post-crisis period has been Switzerland.

(Here figure 9)

During the pre-crisis period unemployment figures did not vary intensively. The variation in percentage points in all studied countries went from $-3.8 \%$ in Spain to 1.1\% in Hungary between 2003 and 2007. As shown in Table 15, older workers unemployment decreased in many studied countries during the pre-crisis period -Germany, Italy, Slovenia, Spain, Sweden and the United Kingdom. The highest variation in the post-crisis period has been recorded by Spain and Greece where unemployment rates for older workers increased more than 10\% between 2008 and 2012.

(Here table 15)

Considering the quantitative indicators, the most concerning one is long-term unemployment. Data supports the idea that this group has a strong labour market position in the national contexts but they risk facing difficulties when trying to find a job once they are unemployed.

Figure 10 shows the evolution of long-term unemployment rate of older workers in all studied countries and the EU28 average between 2008 and 2012. In 2012, 58.8\% of older workers were affected by long-term unemployment in the EU28. The countries with higher figures are Belgium (73.6\%), Greece (67.1\%) and Germany (63\%). Also Hungary, the Netherlands and Spain have figures slightly over the EU28. It is worth noting that two of the countries with higher longterm unemployment rates in the EU28, Belgium and Germany, recorded a downward tendency for the post-crisis period. Other countries where long-term unemployment figures decreased were the Netherlands, Slovenia and Switzerland.

(Here figure 10)

Table 16 shows the variation in percentage, before and after 2008, of long-term unemployment figures among older workers. In the Netherlands, Germany and Switzerland these figures changed from an upward to a downward trend between 2003 and 2007 to the period between 2008 and 2012. Conversely, in Hungary, Italy, Spain, Sweden and the United Kingdom the decreasing tendency of these figures during the pre-crisis period changed to an increasing tendency during the post-crisis period.

(Here table 16)

The worst evolution was recorded by Spain where long-term unemployed of older workers increased by $20.8 \%$ between 2008 and 2012, followed by the United Kingdom with an increase of $17.9 \%$ and Greece with an increase of $8.1 \%$. On the other hand, the Netherlands, Switzerland, Germany and Slovenia recorded the most favourable evolution for long-term unemployment of older workers - with a decrease of $8.4 \%, 8.5 \%, 8.6 \%$ and $13.7 \%$ respectively - and improved their labour market position considerably from a comparative perspective considering long-term unemployment. 


\section{Conclusions}

The most important conclusion is that young people were a vulnerable group in this study, considering the national context before the crisis, in the light of the data which has been analyzed from a comparative approach in a European context.

Conclusions cannot be drawn considering the indicators independently, or that the same indicator has the same meaning for all groups. For example, temporary employment among people aged between 15 and 24 has not the same implications as among people aged between 55 and 64 . High rates of part-time employment cannot be considered per se a negative indicator since in some age cohorts' workers may prefer this kind of contract to reconcile working life with family or education.

High rates of temporary employment might not represent a problem among this age cohort if it is accompanied by low rates of long-term unemployment; young people can move across different jobs whilst acquiring experience. However, a high unemployment rate is always a negative indicator as it is based on the number of the people that are willing to work and cannot do so.

Youth is characterized by high unemployment and low long-term unemployment within the national context of all studied countries; low employment rates and high inactivity rates do not necessarily represent a problem as a high number of those aged between 15 and 24 might still be in full-time education or other kind of training.

In analyzing qualitative indicators, youth had either high levels of part-time employment or high levels of temporary employment which indicates that their labour performance could be more precarious even considering that some people choose to be part-time employed.

Even if young people were clearly vulnerable during the pre-crisis period in all national contexts studied, the labour market position differs from one country to another. In any case the indicators that better represent the labour market position of youth in all studied countries are the unemployment rate and the qualitative indicators - part-time and temporary employment.

One of the indicators that present worse figures over the pre and post-crisis period among the migrant working population compared to the general working population and other groups is the unemployment rate. This rate has been higher than the national average in all studied countries during the post-crisis period, except Greece until 2009, Hungary in 2010 and 2011, and Switzerland in 2008 and 2009.

Older workers had a good position in the national contexts during the pre-crisis period in quantitative terms, except regarding the long-term unemployment. Looking at the qualitative dimension, their labour market position was also very favourable as the fixed-term contracts were less common in all studied countries except the UK - whose temporary employment rate among the general population was the lowest- and although a higher percentage of older workers were part-time employees.

The most concerning aspect of the labour position of older workers is undoubtedly long-term unemployment. Their position can be considered positive in the national contexts but already before the crisis long-term unemployment rates for this age group was over the national average and, in effect, unemployment rates of older workers were under the average in the pre and post-crisis period in all studied countries.

The data for part-time employment rate is not enough to make conclusions on how this affects the labour position of this group, as data does not discriminate people who voluntarily work part-time from those who do not have any choice. Especially among older workers, a percentage of whom might not prefer to work full-time so that they can make work compatible with other activities.

\section{References}

Andrei, J., \& Saša, S. (2011). Especially vulnerable groups in EU and Serbian labor market. MPRA Paper. Retrieved from: http://mpra.ub.uni-muenchen.de/35285/1/MPRA_paper_35285.pdf 
Bahadur, A.V., Ibrahim, M., \& Tanner T. (2010). The resilience renaissance? Unpacking of resilience for tackling climate change and disasters. CSR Discussion Paper No.1, Strengthening Climate Resilience programme, Brighton: IDS. Retrieved from: http://www.fsnnetwork.org/sites/default/files/ids_resilience-renaissance.pdf

Bigos, M., Qaran, W., Fenger, M., Koster, F., Mascini, P., \& van deer Veen, R. (2013). Review essay on labour market resilience [D1.1]. Retrieved from: http://www.inspiresresearch.eu/userfiles/D1_1\%20Review\%20Essay\%20on\%20Labour\%20Market\%20Resilience.pdf

Bonoli, G. (2012). The postindustrial employment problem and active labour market policy. Paper. Retrieved from: http://www.espanet2012.info/_data/assets/pdf_file/0017/90206/Plenary___Bonoli.pdf

Brada, J., \& Signorelli, M. (2012). Comparing Labor Market Performance: Some Stylized Facts and Key Findings. Comparative Economic Studies, 54, 231-250.

Caporale, G.M., \& Gil-Alana, L. (2014). Youth Unemployment in Europe: Persistence and Macroeconomic Determinants. Comparative Economic Studies, 56, 581-591.

Chapple, K., \& Lester, B. (2010). The resilient regional labour market? The US case. Cambridge Journal of Regions. Economy and Society, 3, 85-104.

Choudhry, T.M., Marelli, E., \& Signorelli, M. (2010). Youth unemployment rate and impact of financial crises. International Journal of Manpower, 33 (1), 76-95.

Cuadrado-Roura, J. R., Martin, R., \& Maroto-Sánchez, A. (2016). The economic crisis in Europe: urban and regional consequences. Cambridge Journal of Regions, Economy and Society, 9, 3-11. DOI: 10.1093/cjres/rsv036

Eichhorst, W., Escudero, V., Marx, P., \& Tobin, S. (2010). The impact of the crisis on employment and the role of labour market institutions. IZA Discussion Paper No. 5320, Institute for the Study of Labor (IZA), Bonn.

Eurobarometer Special Surveys (2012). Active ageing Report. 378. Retrieved from:

http://ec.europa.eu/public_opinion/archives/eb_special_379_360_en.htm

Eurofound (2011). Europe's coming of age. Retrieved from:

http://www.eurofound.europa.eu/pubdocs/2011/661/en/2/EF11661EN.pdf

European Agency for Safety and Health at Work (2009). Workforce diversity and risk assessment: ensuring everyone is covered. Retrieved from: https://osha.europa.eu/en/teaser/Workforce_diversity_risk_assessment

European Commission (2011). Employment and Social Developments in Europe 2011. Retrieved from: http://ec.europa.eu/employment_social/esde/2011/

European Commission (2012a). Communication from the commission to the european parliament, the council, the European economic and social committee and the committee of the regions-Towards a job-rich recovery. Strasbourg. Retrieved from: http://eurlex.europa.eu/LexUriServ/LexUriServ.do?uri=COM:2012:0173:FIN:EN:PDF

European Commission. (2012b). Labour Market Developments in Europe, 2012. Economic and Financial Affairs. Retrieved from: http://ec.europa.eu/economy_finance/publications/european_economy/2012/pdf/ee-2012-5_en.pdf

Fenger, M., Koster, F., Struyven, L., \& van der Veen, R. (2014). Smart Policies or Sheer Luck? Labour Market Resilience in the Low Countries. Social policy and administration, 48 (4), 492-513.

ILO (2010a). Employment and social protection in the demographic context. Geneva. Retrieved from:

http://www.ilo.org/wcmsp5/groups/public/@ed_emp/@emp_policy/documents/publication/wcms_125308.pdf

ILO (2011). Equality at work. The continuing challenge. Geneva. Retrieved from:

http://www.ilo.org/wcmsp5/groups/public/@ed_norm/@relconf/documents/meetingdocument/wcms_154779.pdf

Kuddo, A. (2012). Public Employment Services, and Activation Policies. Washington DC: World Bank.

Lallement, M. (2011). Europe and the economic crisis: forms of labour market adjustment and varieties of capitalism. Work, employment and society, 25 (4), 627-641.

Lisnyak, S. (2015). Literature review regarding the concept of resilience and its assessment in the context of the economic dimension. CES Working Papers, issue: 2A, 511-518.

Marelli, E., Signorelli, M., \& Tyrowicz, J. (2012). Crises and joint employment-productivity dynamics: A comparative perspective for European countries. Comparative Economic Studies, 54 (2), 361-394. 
Martin, R. (2012). Regional Economic Resilience, Hysteresis and Recessionary Shocks. Journal of Economic Geography, 12 (1), 1-32. DOI: $10.1093 / \mathrm{jeg} / \mathrm{lbr} 019$

Martin, R., \& Sunley, P. (2014). On the Notion of Regional Economic Resilience: Conceptualisation and Explanation. Journal of Economic Geography, 15 (1), 1-42. DOI: 10.1093/jeg/lbu015

Murias, P., Martínez-Roget, F., Novello, S., \& Estévez-Núñez, J.C. (2012). Resiliencia y mercados de trabajo locales: municipios españoles frente a la crisis, International Conference on Regional Science the challange of regional development in a world of changing hegemonies: knowledge, competitiveness and austerity, XXXVIII Reunión de Estudios Regionales- AECR. Retrieved from: http://www.aecr.org/web/congresos/2012/Bilbao2012/htdocs/pdf/p380.pdf

OECD (2012). OECD Employment Outlook 2012, Paris. OECD Publishing. DOI: http://dx.doi.org/10.1787/empl_outlook-2012-en

Rueda, D. (2012). Dualization and Crisis. Swiss Political Science Review, 18 (4), 523-530.

Simmie, J., \& Martin, R. (2010). The economic resilience of regions: towards an evolutionary approach. Cambridge Journal of Regions, Economy and Society, 3, 27-43. DOI:10.1093/cjres/rsp029

Vaughan-Whitehead, D. (2011). The effects of the crisis on work inequalities in Europe. Research Conference on Key Lessons from the Crisis and Way Forward. Retrieved from: http://www.llo.org/wcmsp5/groups/public/---dgreports/--inst/documents/genericdocument/wcms_192381.pdf

Verick, S. (2009). Who Is Hit Hardest during a Financial Crisis? The Vulnerability of Young Men and Women to Unemployment in an Economic Downturn. Discussion Paper No. 4359. Institute for the Study of Labor (IZA), Bonn.

Acknowledgement

Martínez-Molina is supported by a pre-doctoral FPU fellowship of the Spanish Ministry of Education (FPU13/05424). Thanks to Estrella Durá for her constructive comments, and to Polibienestar Research Institute (University of Valencia) and the Spanish Ministry of Education for their support.

\section{Conflict of Interest}

The authors declare that they have no conflict of interest.

\section{Endnotes}

Tables

Table 1: Definition of vulnerable groups

\begin{tabular}{|l|l|}
\hline $\begin{array}{l}\text { Vulnerable } \\
\text { group }\end{array}$ & Definition \\
\hline Youth & $\begin{array}{l}\text { Youth labour force comprises all persons between the age of } 15 \text { and } 24 \text { who were either employed or unemployed } \\
\text { over a specified reference period. }\end{array}$ \\
\hline Migrants & $\begin{array}{l}\text {-Foreign citizens (non-nationals) are defined as persons who do not hold the citizenship of their country of residence, } \\
\text { regardless of whether they were born in that country or elsewhere. } \\
\text {-Second-generation migrants, (i.e. either those with one parent or two parents born abroad) refer to two different } \\
\text { groups of immediate descendants of migrants. The first group with a mixed background is defined as persons who } \\
\text { are native born and who have one foreign-born parent and one native-born parent. The second group, with a foreign } \\
\text { background, is defined as persons who are native born with both parents foreign-born. }\end{array}$ \\
\hline $\begin{array}{l}\text { Older } \\
\text { workers }\end{array}$ & $\begin{array}{l}\text { The number of persons (females, males) aged 55-64 in employment as a share of the total population (females, } \\
\text { males) of the same age group. }\end{array}$ \\
\hline
\end{tabular}

Source: Source: Bigos et al. (2013)

Table 2: Sample

\begin{tabular}{|l|l|}
\hline Belgium & $\mathrm{BE}$ \\
\hline Germany & $\mathrm{DE}$ \\
\hline Greece & $\mathrm{GR}$ \\
\hline Hungary & $\mathrm{HU}$ \\
\hline Italy & $\mathrm{IT}$ \\
\hline The Netherlands & $\mathrm{NL}$ \\
\hline
\end{tabular}




\begin{tabular}{|l|l|}
\hline Slovenia & SI \\
\hline Spain & ES \\
\hline Sweden & SE \\
\hline Switzerland & CH \\
\hline United Kingdom & UK \\
\hline
\end{tabular}

Table 3: Labour position operationalization

\begin{tabular}{|ll|}
\hline Quantitative domain & Qualitative domain \\
\hline Unemployment rate & Temporary employment \\
Long-term unemployment & Part-time employment \\
\hline
\end{tabular}

Table 4: Indicators from Eurostat Labour market statistics used

\begin{tabular}{|c|c|c|c|c|}
\hline Vulnerable groups & \multirow[t]{2}{*}{ Migrants } & \multirow[t]{2}{*}{ Youth } & \multirow[t]{2}{*}{ Older workers } & \multirow[t]{2}{*}{ General population } \\
\hline Indicators & & & & \\
\hline $\begin{array}{l}\text { Unemployment rate } \\
\text { (Ifsa_unemp) }\end{array}$ & $\begin{array}{l}\text { Age: } 15-65 \\
\text { Nationality :Foreign country } \\
\text { (Ifsa_urgan) }\end{array}$ & $\begin{array}{l}\text { Age: } 15-24 \\
\text { Nationality: all } \\
\text { (lfsa_urgan) }\end{array}$ & $\begin{array}{l}\text { Age: } 55-64 \\
\text { Nationality: all } \\
\text { (Ifsa_urgan) }\end{array}$ & $\begin{array}{l}\text { Age: } 15-64 \\
\text { Nationality: all } \\
\text { (lfsa_urgan) }\end{array}$ \\
\hline $\begin{array}{l}\text { Long-term } \\
\text { unemployment } \\
\text { (Ifsa_unemp) }\end{array}$ & $x$ & $\begin{array}{l}\text { Age: } 15-24 \\
\text { Nationality: all } \\
\text { (Ifsa_upgal) }\end{array}$ & $\begin{array}{l}\text { Age: } 55-64 \\
\text { Nationality: all } \\
\text { (Ifsa_upgal) }\end{array}$ & $\begin{array}{l}\text { Age: } 15-64 \\
\text { Nationality: all } \\
\text { (lfsa_upgal) }\end{array}$ \\
\hline $\begin{array}{l}\text { Temporary employment } \\
\text { (Ifsa_emptemp) }\end{array}$ & $\begin{array}{l}\text { Age: } 15-74 \\
\text { Nationality: Foreign country } \\
\text { (Ifsa_etpgan) }\end{array}$ & $\begin{array}{l}\text { Age: } 15-24 \\
\text { (Ifsq_etpga) }\end{array}$ & $\begin{array}{l}\text { Age: } 55-64 \\
\text { (Ifsq_etpga) }\end{array}$ & $\begin{array}{l}\text { Age: } 15-54 \\
\text { (Ifsq_etpga) }\end{array}$ \\
\hline $\begin{array}{l}\text { Full-time and part-time } \\
\text { employment } \\
\text { (Ifsa_empftpt) }\end{array}$ & $\begin{array}{l}\text { Age: } 15-64 \\
\text { Nationality: Foreign country } \\
\text { (Ifsa_eppgan) }\end{array}$ & $\begin{array}{l}\text { Age: } 15-24 \\
\text { Nationality: all } \\
\text { (Ifsa_eppgan) }\end{array}$ & $\begin{array}{l}\text { Age: } 55-64 \\
\text { Nationality: all } \\
\text { (Ifsa_eppgan) }\end{array}$ & $\begin{array}{l}\text { Age: } 15-64 \\
\text { Nationality: all } \\
\text { (Ifsa_eppgan) }\end{array}$ \\
\hline
\end{tabular}

Table 5: Youth unemployment variation for all studied countries and the EU28 average, between 2000 and 2007, people aged between 15 and 24 years old - in percentage points.

\begin{tabular}{|l|l|l|l|l|l|l|l|l|l|l|l|}
\hline EU28 & BE & DE & GR & HU & IT & NL & SI & ES & SE & CH & UK \\
\hline$-2,8$ & 3,6 & 3,4 & $-6,5$ & 5,7 & $-11,2$ & 0,6 & $-6,3$ & $-7,2$ & 9,8 & 2,1 & 2,3 \\
\hline
\end{tabular}

Table 6: Youth part-time employment variation for all studied countries and the EU28 average, between 2000 and 2007, people aged between 15 and 24 years old - in percentage points

\begin{tabular}{|l|l|l|l|l|l|l|l|l|l|l|l|}
\hline EU28 & BE & DE & GR & HU & IT & NL & SI & ES & SE & CH & UK \\
\hline 4,5 & $-1,7$ & 8,4 & 3,0 & 2,8 & 7,3 & 8,2 & 16,4 & 7,7 & 1,6 & 2,4 & 1,2 \\
\hline
\end{tabular}

Table 7: Youth unemployment variation for all studied countries and the EU28 average, people aged between 15 and 24 years old in percentage (gap in percentage points)

\begin{tabular}{|l|l|l|l|l|l|l|l|l|l|l|l|l|}
\hline & EU28 & BE & DE & GR & HU & IT & NL & SI & ES & SE & CH & UK \\
\hline $2003-2007$ & $-2,8$ & 3,6 & 3,4 & $-6,5$ & 5,7 & $-11,2$ & 0,6 & $-6,3$ & $-7,2$ & 9,8 & 2,1 & 2,3 \\
\hline $2008-2012$ & 7,3 & 1,8 & $-2,5$ & 33,4 & 8,2 & 14,0 & 4,2 & 10,2 & 28,4 & 3,4 & 1,4 & 6,0 \\
\hline Gap & 10,1 & $-1,8$ & $-5,9$ & 39,9 & 2,5 & 25,2 & 3,6 & 16,5 & 35,6 & $-6,4$ & $-0,7$ & 3,7 \\
\hline
\end{tabular}

Table 8: Youth temporary employment rates for all INSPIRES countries and the EU28 average, in 2000 and 2007, people aged between 15 and 24 years old - in percentage.

\begin{tabular}{|l|l|l|l|l|l|l|l|l|l|l|} 
BE & DE & GR & HU & IT & NL & SI & ES & SE & CH & UK \\
\hline
\end{tabular}




\begin{tabular}{|l|l|l|l|l|l|l|l|l|l|l|l|}
\hline 2000 & 30,9 & 52,4 & 29,6 & 68,9 & 26,2 & 12,7 & 35,3 & 43,2 & 45,2 & 13,2 & 47 \\
\hline 2007 & 31,6 & 57,4 & 26,5 & 62,7 & 42,3 & 19,1 & 45,1 & 68,3 & 57,1 & 13,3 & 50,3 \\
\hline
\end{tabular}

Table 9: Migrants' unemployment variation for all INSPIRES countries and the EU28 average, between 2000 and 2007, - in

\begin{tabular}{|l|l|l|l|l|l|l|l|l|l|l|l|l|}
\hline EU28 & BE & DE & GR & HU & IT & NL & SI & ES & SE & CH & UK \\
\hline$-1,6$ & $-0,1$ & 3,4 & $-4,0$ & 0,0 & 8,3 & $-0,7$ & 9,7 & $-2,2$ & $-1,6$ & 1,5 & $-2,3$ \\
\hline
\end{tabular}

Table 10: Temporary employment rates for migrants and the general population for all studied countries, in 2007 - in percentage (gap in percentage points)

\begin{tabular}{|l|l|l|l|l|l|l|l|l|l|l|l|}
\hline & $\mathrm{BE}$ & $\mathrm{DE}$ & $\mathrm{GR}$ & $\mathrm{HU}$ & $\mathrm{IT}$ & $\mathrm{NL}$ & $\mathrm{SI}$ & $\mathrm{ES}$ & $\mathrm{SE}$ & $\mathrm{CH}$ & $\mathrm{UK}$ \\
\hline General & 8,7 & 14,6 & 11,0 & 7,3 & 13,2 & 18,1 & 18,5 & 31,6 & 17,5 & 12,9 & 5.8 \\
\hline Migrant & 14,4 & 17,5 & 16,3 & 14,1 & 14,8 & 32,2 & 32,6 & 54,3 & 22,3 & 13,7 & 10,9 \\
\hline Gap & 5,7 & 2,9 & 5,3 & 6,8 & 1,6 & 14,1 & 14,1 & 22,7 & 4,8 & 0,8 & 5,1 \\
\hline
\end{tabular}

Table 11: Migrant people unemployment variation for all studied countries and the EU28 average, between 2000 and 2007, and between 2008 and 2012, in percentage points

\begin{tabular}{|l|l|l|l|l|l|l|l|l|l|l|l|l|}
\hline & EU28 & BE & DE & GR & HU & IT & NL & SI & ES & SE & CH & UK \\
\hline $2000-2007$ & $-1,6$ & $-0,1$ & 3,4 & $-4,0$ & --- & 8,3 & $-0,7$ & 9,7 & $-2,2$ & $-1,6$ & 1,5 & $-2,3$ \\
\hline $2008-2012$ & 5,5 & 3,0 & $-3,7$ & 26,6 & $-0,1$ & 5,6 & 4,0 & 9,2 & 18,5 & 6,7 & 1,2 & 2,2 \\
\hline
\end{tabular}

Table 12: Migrant people part-time employment variation for all studied countries and the EU28 average, between 2000 and 2007, and between 2008 and 2012, in percentage points

\begin{tabular}{|l|l|l|l|l|l|l|l|l|l|l|l|l|}
\hline & EU28 & BE & DE & GR & HU & IT & NL & SI & ES & SE & CH & UK \\
\hline $2000-2007$ & 2,1 & 2,0 & 11,7 & $-2,5$ & -- & 17,9 & 2,9 & 0,0 & 1,9 & 2,9 & 2,6 & $-3,6$ \\
\hline $2008-2012$ & 4,5 & 1,7 & 1,8 & 11,2 & 9,7 & 6,6 & 0,8 & 2,8 & 8,0 & 0,5 & 2,8 & 3,2 \\
\hline
\end{tabular}

Table 13: Older workers' unemployment variation for all STUDIED countries and the EU28 average, between 2000 and 2007,

\begin{tabular}{|c|c|c|c|c|c|c|c|c|c|c|c|}
\hline EU28 & BE & DE & GR & HU & IT & NL & SI & ES & SE & CH & UK \\
\hline$-1,8$ & 1,0 & $-2,4$ & $-0,3$ & 1,1 & $-2,3$ & 1,7 & $-2,8$ & $-3,8$ & $-1,9$ & 0,4 & $-1,3$ \\
\hline
\end{tabular}

Table 14: Older workers long-term unemployment variation for all studied countries and the EU28 average, between 2000 and 2007, people aged between 55 and 64 years old

\begin{tabular}{|c|c|c|c|c|c|c|c|c|c|c|c|}
\hline EU28 & BE & DE & GR & HU & IT & NL & SI & ES & SE & CH & UK \\
\hline 1,8 & $-4,3$ & 8,0 & 2,7 & $-3,7$ & $-10,0$ & 13,8 & $-26,9$ & $-12,8$ & $-22,7$ & 15,9 & $-6,5$ \\
\hline
\end{tabular}

Table 15: Unemployment variation in percentage points for older workers for pre-crisis period (2003-2007) and post-crisis period (2008-2012)

\begin{tabular}{|l|l|l|l|l|l|l|l|l|l|l|l|l|}
\hline & EU28 & BE & DE & GR & HU & IT & NL & SI & ES & SE & CH & UK \\
\hline $2003-2007$ & $-1,0$ & 2,5 & $-2,3$ & 0,3 & 1,3 & $-1,8$ & 1,4 & $-0,6$ & $-0,8$ & $-0,5$ & 0,6 & $-0,1$ \\
\hline $2008-2012$ & 2,3 & 0,1 & $-2,6$ & 10,3 & 2,9 & 2,2 & 1,5 & 2,2 & 10,6 & 1,4 & 0,5 & 1,8 \\
\hline
\end{tabular}

Table 16: Long-term unemployment variation in percentage points for older workers for pre-crisis period (2003-2007) and postcrisis period (2008-2012)

\begin{tabular}{|l|l|l|l|l|l|l|l|l|l|l|l|l|}
\hline & EU28 & BE & DE & GR & HU & IT & NL & SI & ES & SE & CH & UK \\
\hline $2003-2007$ & 1,8 & $-4,3$ & 8,0 & 2,7 & $-3,7$ & $-10,0$ & 13,8 & $-26,9$ & $-12,8$ & $-22,7$ & 15,9 & $-6,5$ \\
\hline $2008-2012$ & 2,0 & $-6,2$ & $-8,6$ & 8,1 & 3,5 & 7,4 & $-8,4$ & $-13,7$ & 20,8 & 5,7 & $-8,5$ & 17,9 \\
\hline
\end{tabular}




\section{Figures}

Figure 1: Youth unemployment rates for all studied countries and the EU28 average, between 2000 and 2007, people aged between 15 and 24 years old.

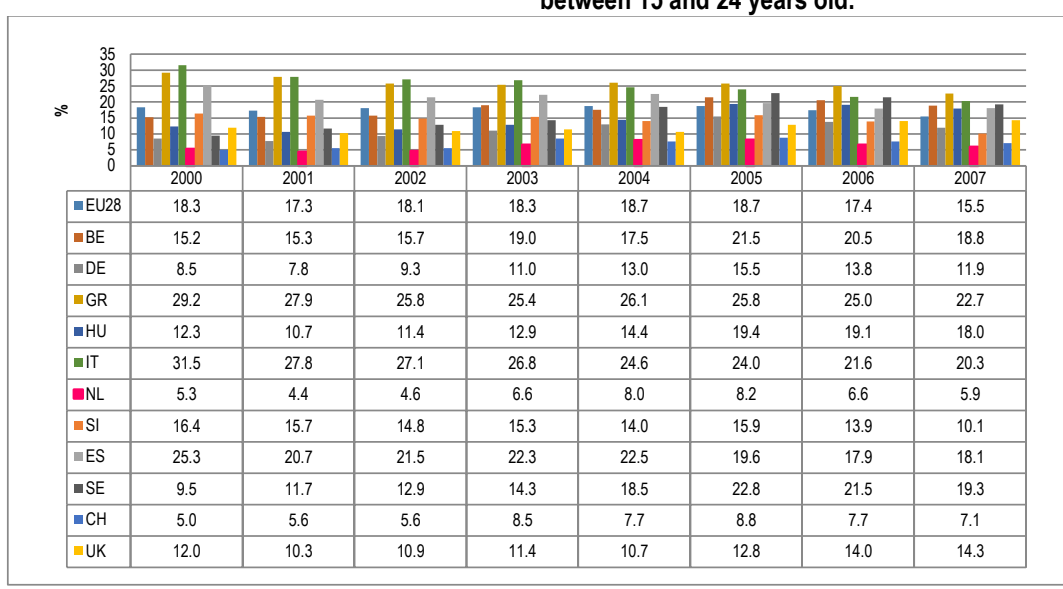

Figure 2: Youth unemployment rates in post-crisis period (2008-2012) for all studied countries and the EU28 average.

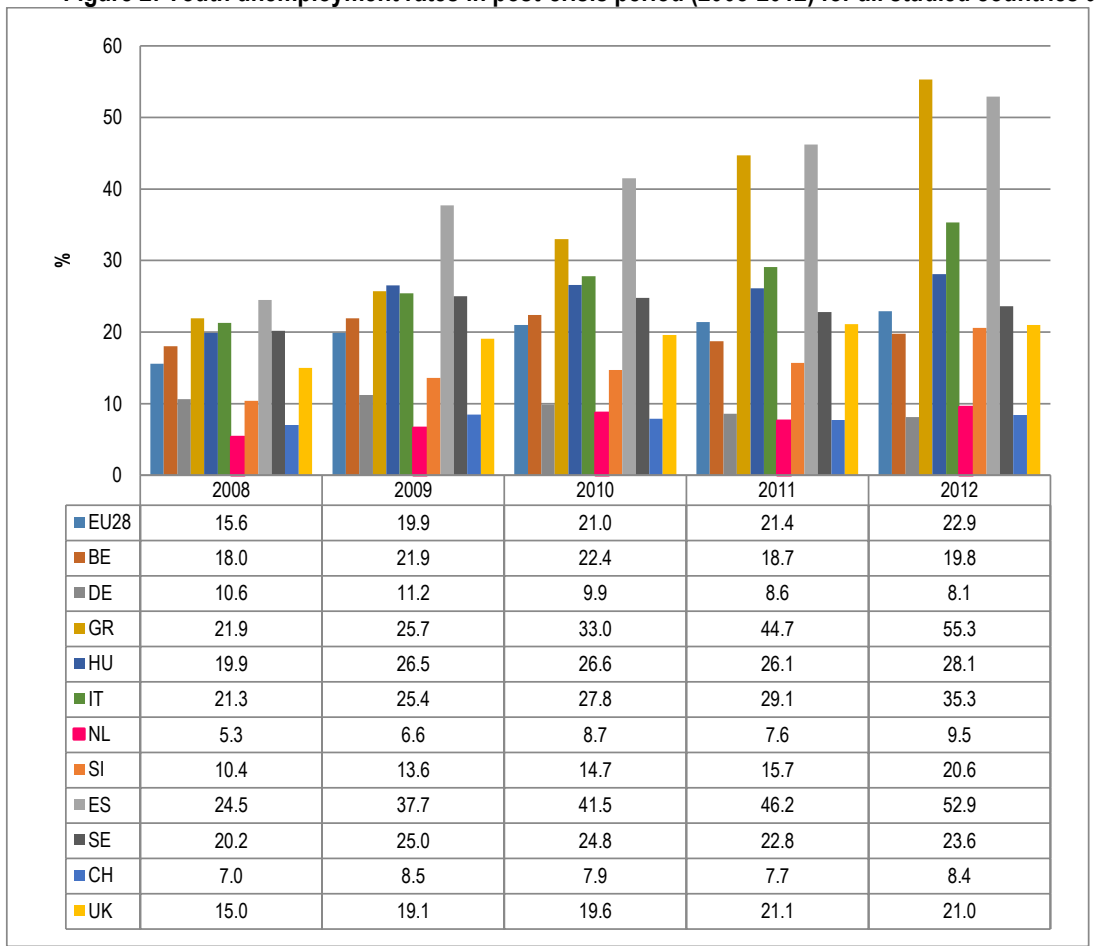


Figure 3: Part-time young employees as percentage of all employees for all studied countries and the EU28 average, between 2000 and 2007, people aged between 15 and 24 years old

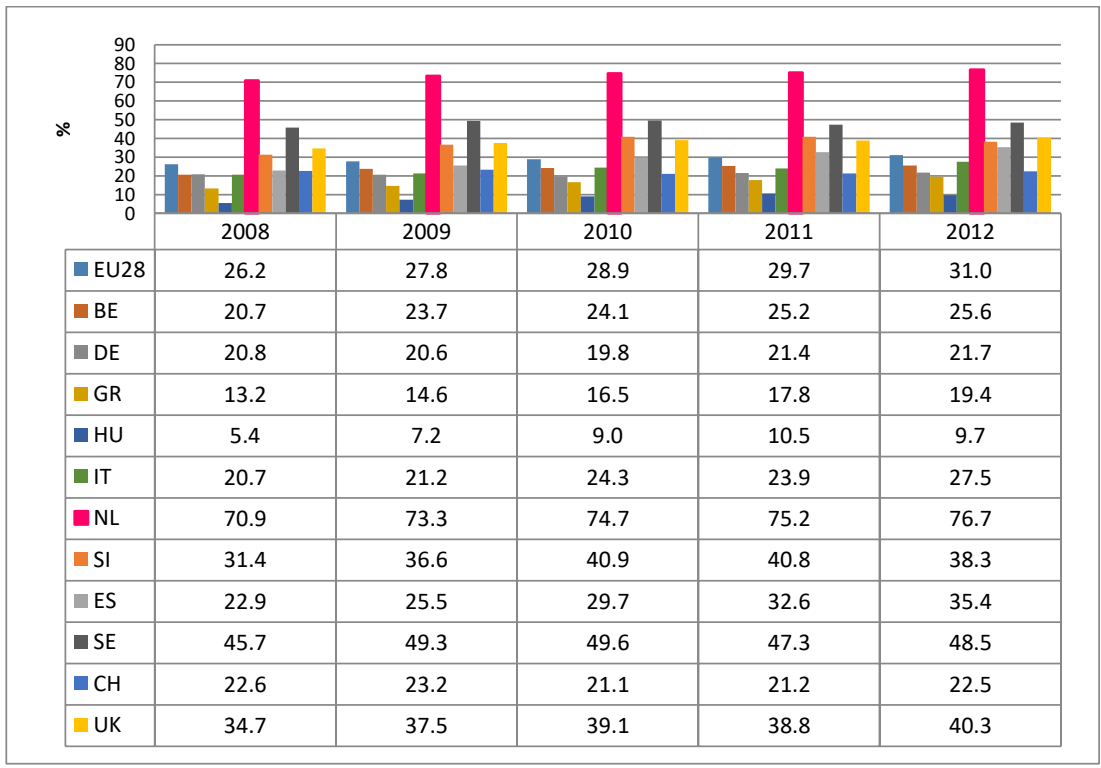

Figure 4: Migrant unemployment rates in pre-crisis period for all INSPIRES countries and the EU28 (15-64 years)

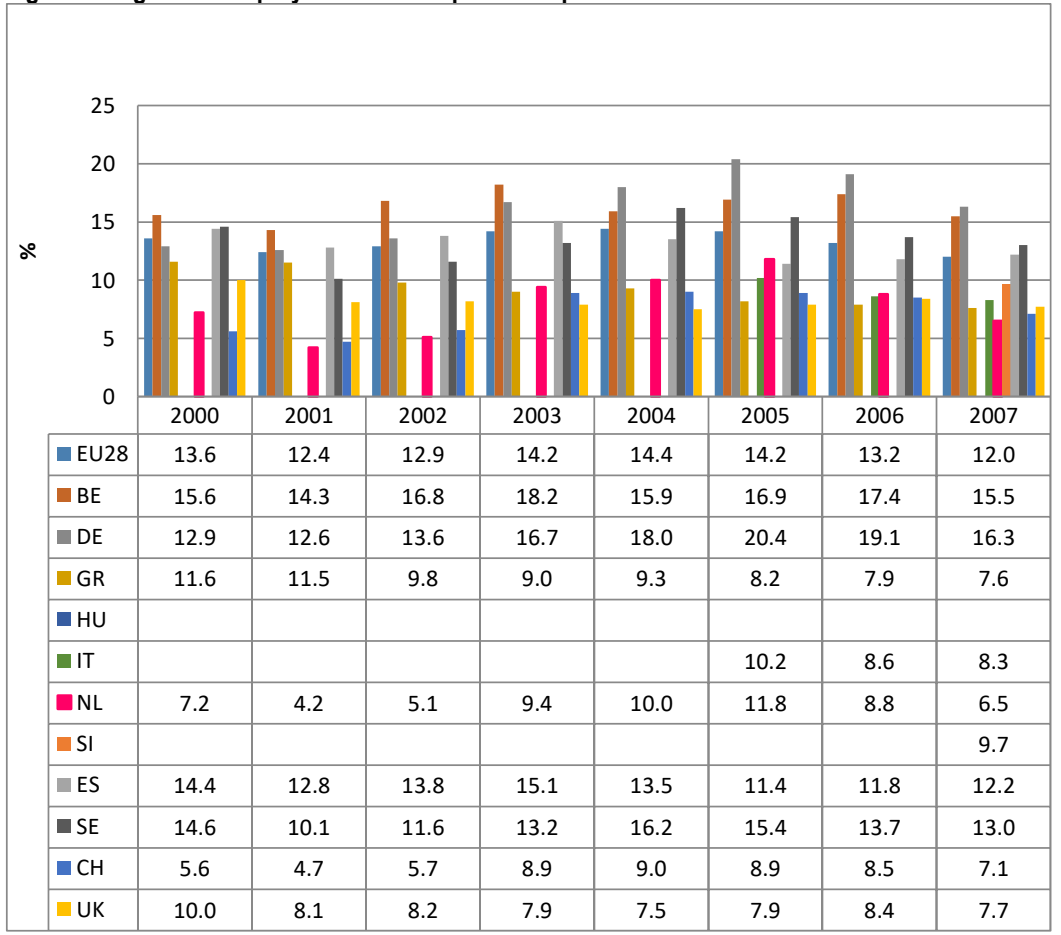


Figure 5: Migrant unemployment rates in post-crisis period for all studied countries and the EU28, between 2008 and 2012, in percentage.

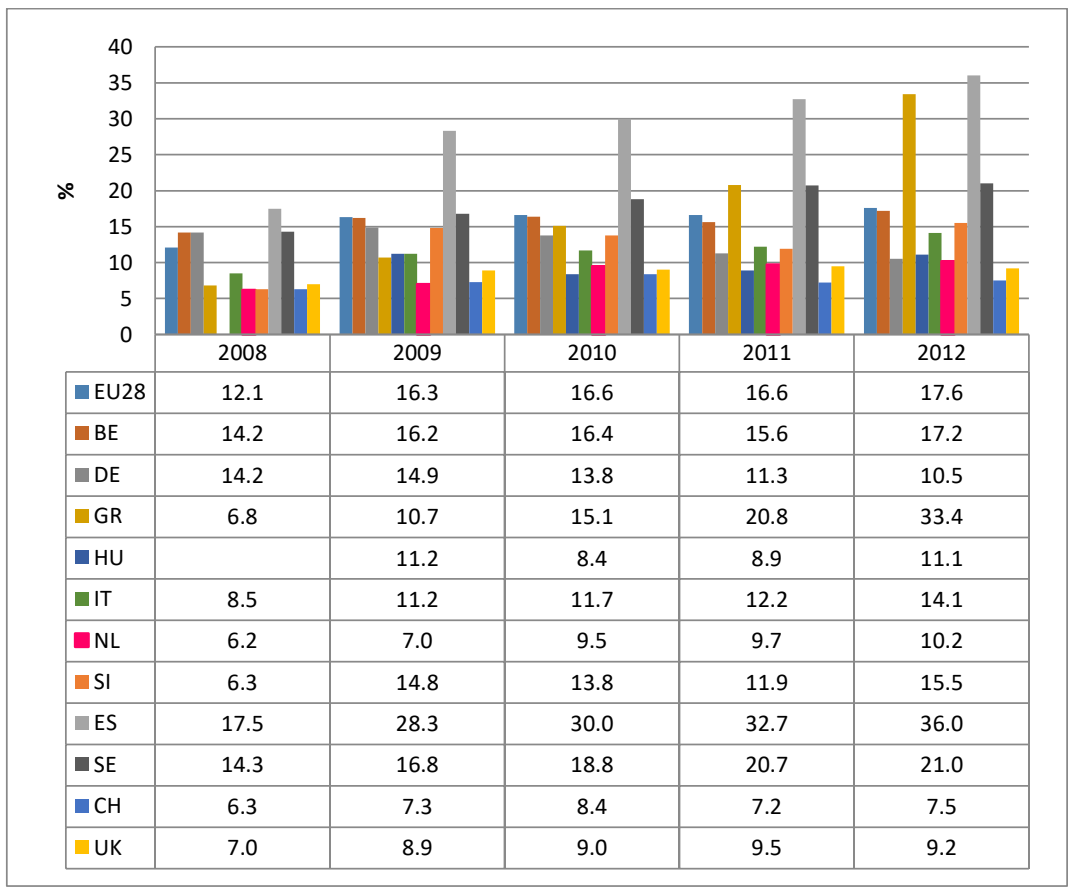

Figure 6: Part-time migrant in post-crisis period for all studied countries and the EU28, between 2008 and 2012, in percentage

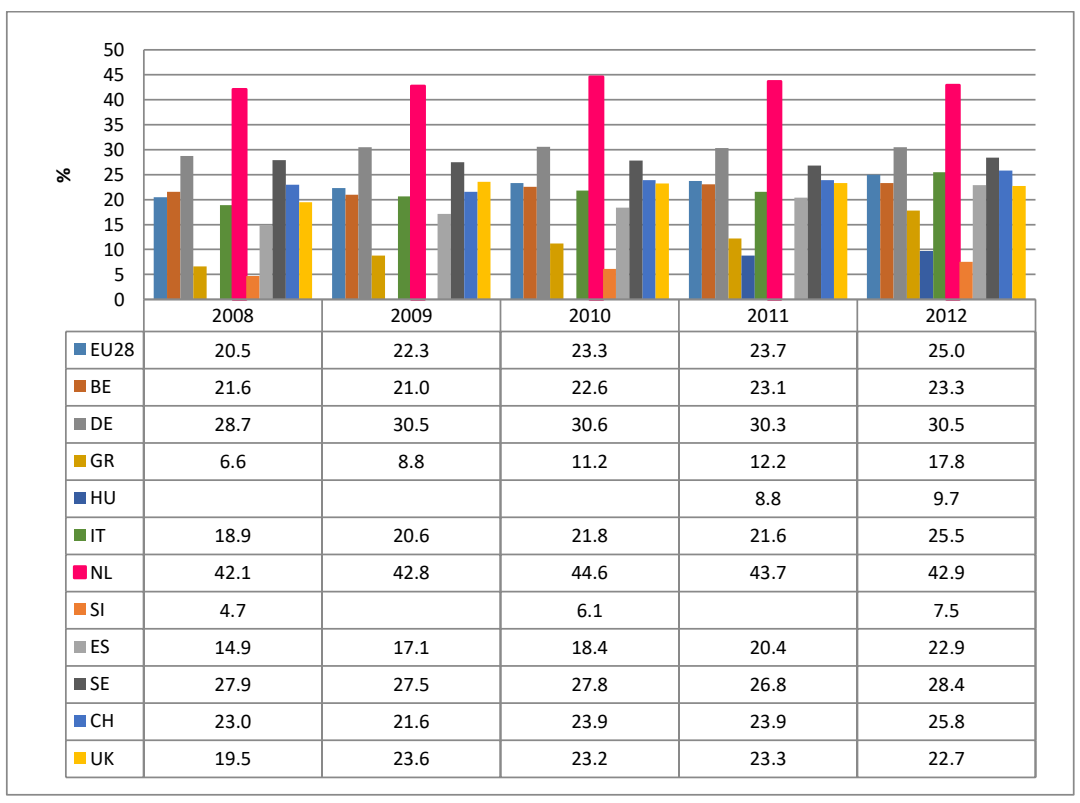


Figure 7: Older workers unemployment rates in pre-crisis period for all STUDIED countries and the EU28 average in percentage

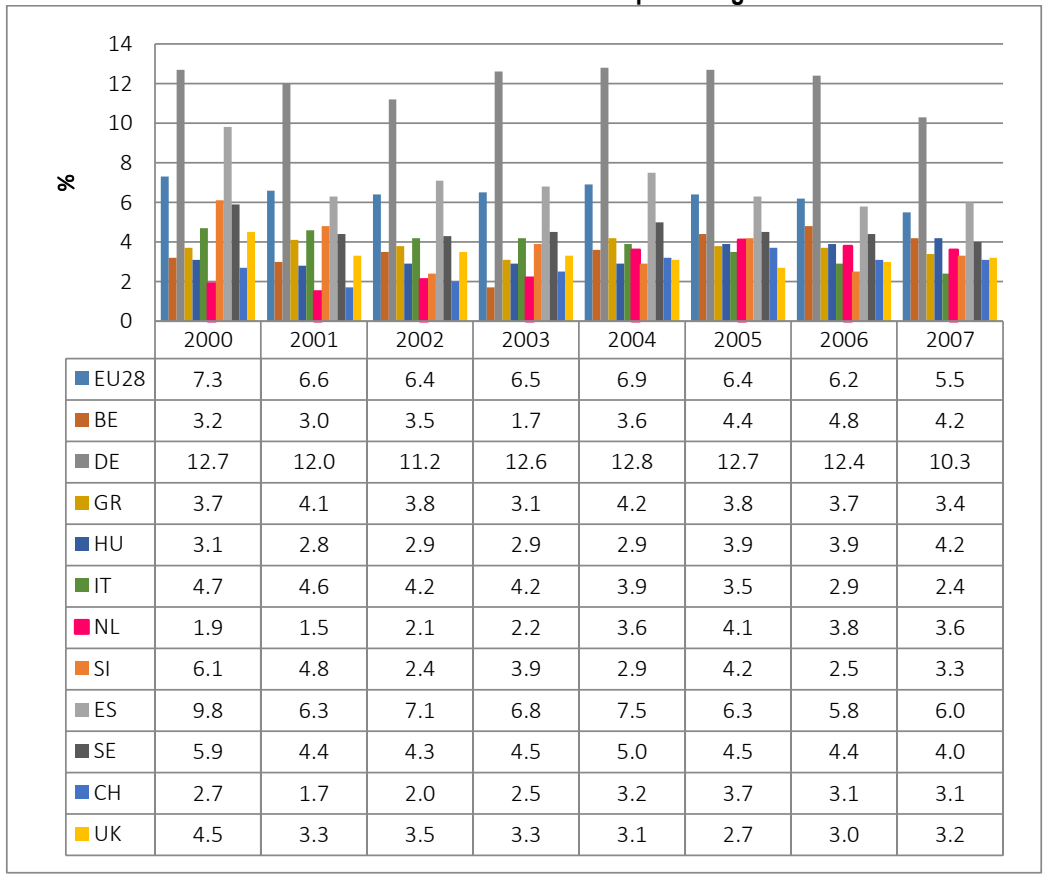

Figure 8: Long-term unemployment rates of older employees in pre-crisis period for all STUDIED countries and the EU28 average

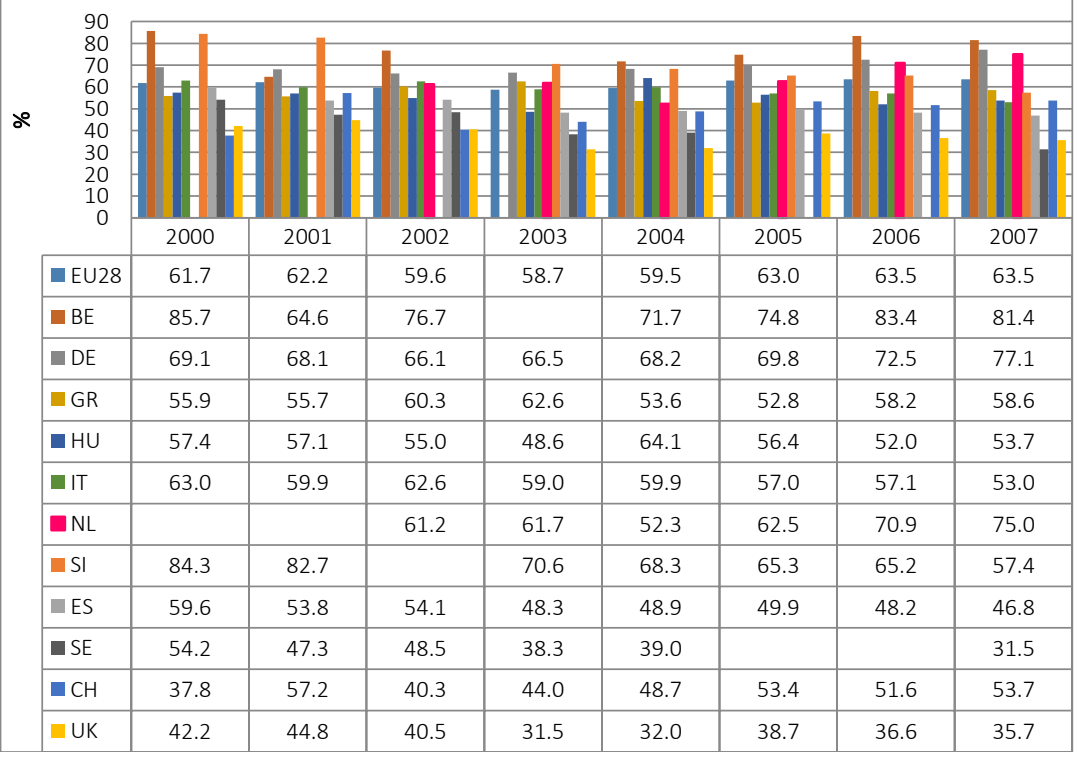


Figure 9: Older workers unemployment rates in post-crisis period for all studied countries and the EU28 average

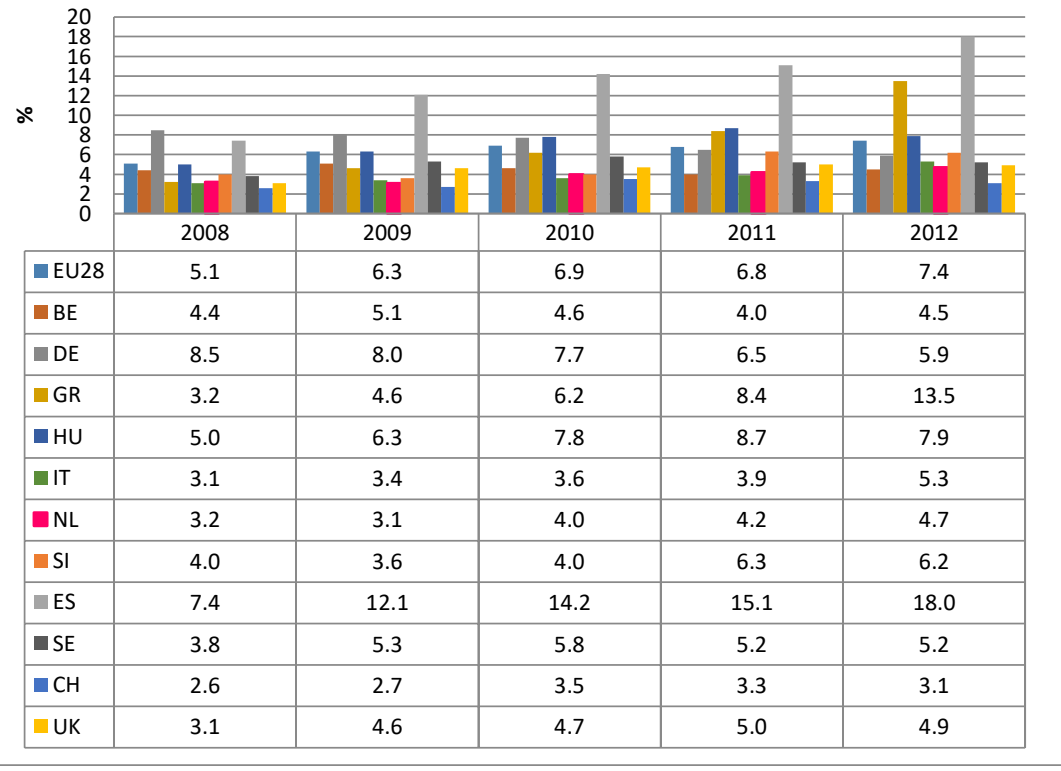

Figure 10: Long-term unemployment rates of older employees in post-crisis period for all studied countries and the EU28 average

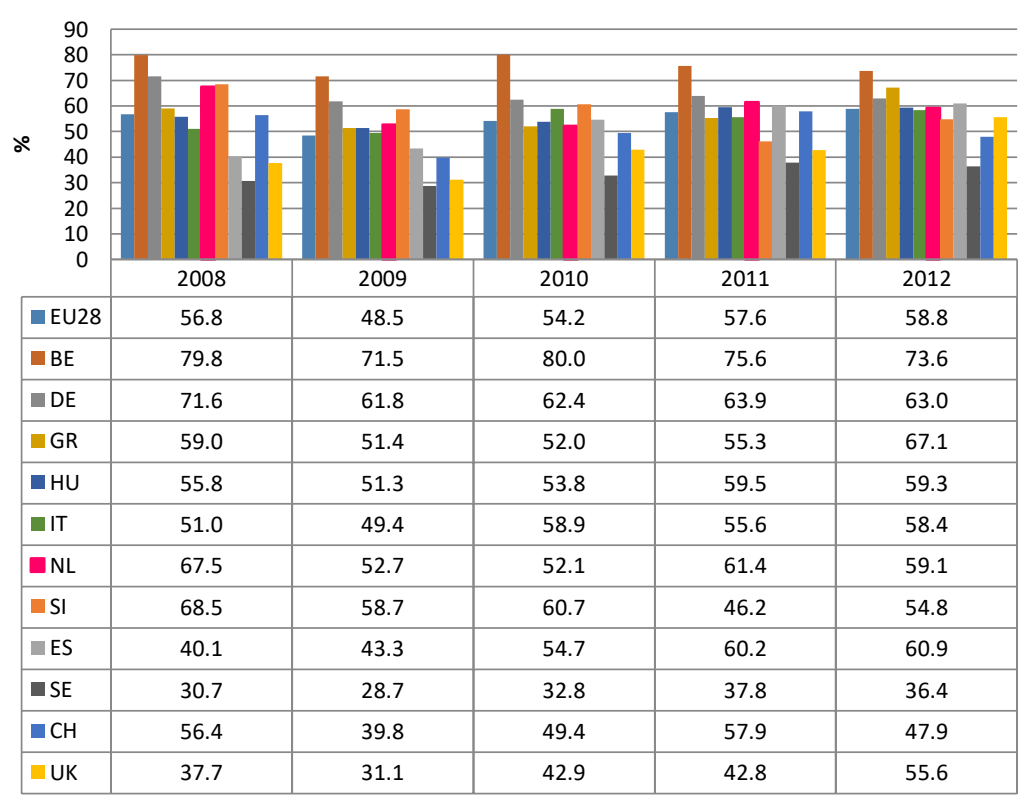

This data is not presented in this paper due to space limitations. 